\section{Plant Regeneration of Pampas Grass from Immature Inflorescences Cultured in Vitro}

\author{
C.D. Robacker and W.L. Corley \\ Department of Horticulture, Georgia Station, Griffin, GA 30223-l797
}

Additional index words. Cortaderia selloana, micropropagation, tissue culture,

organogenesis, Gramineae

\begin{abstract}
A micropropagation system to obtain plants from inflorescences of pampas grass (Cortaderia selloana Schult. 'Pumila') was developed. Factors examined included developmental stage of inflorescence cultured and growth regulator combinations and concentrations that support explant establishment, shoot regeneration, and rooting. Immature inflorescences $\approx 300 \mathrm{~mm}$ long formed many shoot primordia when initially cultured on Murashige and Skoog basal medium containing 4.5 $\mu \mathrm{M}$ 2,4-D and $8.9 \mu \mathrm{M}$ BA and subcultured to medium with $0.4 \mu \mathrm{M} 2,4-\mathrm{D}$ and $4.4 \mu \mathrm{M}$ BA. Thereafter, monthly transfer to a medium without growth regulators yielded about three shoots per tube per month for more than 6 months. Most shoots rooted spontaneously and were easily hardened to greenhouse conditions. Field-tested plants flowered within 2 years and nearly all appeared identical to the parent cultivar. With this technique, several thousand plants can be obtained from a single inflorescence in 1 year. Chemical names used: $N$-(phenylmethyl)-1 $H$-purine-6-amine (BA); (2,4-dichlorophenoxy)acetic acid (2,4-D).
\end{abstract}

Pampas grass is an ornamental grass that is prized for its stately appearance and large, showy plumes (Meyer, 1975). Pampas grass is dioecious, and the female plants have more attractive plumes. To obtain only female plants and to maintain cultivar identity, pampas grass cultivars are propagated through division, which yields about a 4-fold increase in plants per year. A more rapid method of propagation, such as in vitro propagation, would be especially desirable for cultivars that are in high demand.

In vitro propagation via somatic embryogenesis or adventitious bud and shoot development has been successful in many species in the Gramineae (Bhaskaran and Smith, 1990; Vasil, 1987). Regenerable cultures have been initiated from immature embryos, seeds, seedlings, shoot meristems, young leaves, and immature inflorescences (Bhaskaran and Smith, 1990). Preliminary studies on the in vitro propagation of pampas grass has revealed that shoots can be obtained from culture of immature inflorescences (Robacker and Corley, 1988; Robacker and Johnson, 1989). The objective of the following study was to determine the conditions for the in vitro propagation of 'Pumila', a popular dwarf cultivar.

General procedures. Unless stated otherwise, immature inflorescences $\approx 300 \mathrm{~mm}$

Received for publication 23 Aug. 1991. Accepted for publication 11 Mar. 1992. A contribution of the Univ. of Georgia Agr. Expt. Sta., Georgia Station, Griffin. We gratefully acknowledge the technical assistance of Betty Robicheaux. This research was supported by state and Hatch Act funds allocated to the Georgia Agr. Expt. Stas. The cost of publishing this paper was defrayed in part by the payment of page charges. Under postal regulations, this paper therefore must be hereby marked advertisement solely to indicate this fact. long, enclosed within the terminal leaves, were collected from two plants grown in the field. The outer leaves were removed, and the cut ends were dipped in melted paraffin wax to prevent the disinfecting agent from penetrating into the interior of the inflorescence. Inflorescences were dipped for $1 \mathrm{~min}$ in $95 \%(\mathrm{v} / \mathrm{v})$ ethanol, soaked for $20 \mathrm{~min}$ in $1 \% \mathrm{NaOCl}$, and rinsed three times with sterile distilled water. The remaining leaves that covered the inflorescences were removed. The inflorescences were cut into segments $\approx 20 \mathrm{~mm}$ long, and three to five segments were positioned horizontally in each culture tube. Culture tubes were maintained at 27 to $30 \mathrm{C}$ with $16 \mathrm{~h}$ of light provided by 110-W wide-spectrum fluorescent bulbs (70 $\left.\mu \mathrm{mol} \cdot \mathrm{m}^{-2} \cdot \mathrm{s}^{-1}\right)$.

The culture medium consisted of MS salts and vitamins (Murashige and Skoog, 1962) and $\left(\mathrm{g} \cdot\right.$ liter $\left.^{-1}\right) 20$ sucrose, $0.75 \mathrm{MgCl}_{2}$, and 2 Gelrite. The $\mathrm{MgCl}_{2}$ was added to replace divalent cations sequestered by Gelrite during gelling. Growth regulators were added (see below), and the $\mathrm{pH}$ was adjusted to 5.5 with $1 \mathrm{~N} \mathrm{NaOH}$. The medium was dispensed in 16-ml aliquots into $25 \times 150$-mm culture tubes capped with clear Magenta caps (Magenta, Chicago) and autoclaved for $20 \mathrm{~min}$ at $121 \mathrm{C}$.

Tissue growth (swelling of the explant, callus formation, and shoot bud development and proliferation) and shoot growth were evaluated on a rating scale from 0 to 5 . Cultures were rated 0 when the tissues died; 1 $=$ at least some tissue survived, but little or no growth occurred; 2 = tissue exhibited some growth, but no more than one leaf or shoot had formed; 3 = tissues had about doubled in size, and leaves, shoot buds, or shoots were present; $4=$ tissues had tripled or quadrupled in size and consisted mostly of shoot buds and/or shoots; and $5=$ the surface of the medium was covered with shoot buds and/or shoots. Rating data were transformed to arcsin values, then subjected to analysis of variance using a general linear model procedure (SAS, 1985). When treatment effects were significant, individual treatment differences were tested with single-degree-of-freedom orthogonal contrasts. A chi-square test was used to detect treatment differences for the presence or absence of roots.

Explant effects. The influence of developmental stage of the inflorescence on plant regeneration was investigated. Developmental stage was measured by the number of days before flowering (emergence from the boot) and inflorescence length. A minimum of 20 explants was cultured from inflorescences of varying maturity, ranging from 33 days before flowering to the day of emergence. This study was conducted in 1988 and 1989. Inflorescence lengths were measured for each inflorescence cultured. To determine whether morphogenesis was affected by position along the inflorescence, inflorescences ( 250 to $300 \mathrm{~mm}$ long) were divided into distal, middle, and proximal segments. Eighteen explants from each segment were cultured. The effect of specific organs on morphogenesis was determined by culturing 12 explants each of floret, rachilla, and rachis tissues of an inflorescence that was $300 \mathrm{~mm}$ long. Culture medium was MS supplemented with $4.5 \mu \mathrm{M} 2,4-\mathrm{D}$ and $8.9 \mu \mathrm{M}$ BA.

Growth regulator effects. Explants from inflorescences were cultured on MS basal medium containing $0,0.4,4.5$, or $9.0 \mu \mathrm{M}$ 2,4-D and $0,4.4,8.9$, or $17.8 \mu \mathrm{M}$ BA. After

Table 1. Effect of 2,4-D and BA on growth ratings of pampas grass inflorescences after 1 month of culture.

\begin{tabular}{clccc}
\hline \hline & \multicolumn{4}{c}{ Mean growth rating } \\
\cline { 2 - 5 } BA & \multicolumn{4}{c}{$2,4-\mathrm{D}(\mu \mathrm{M})$} \\
\cline { 2 - 5 }$(\mu \mathrm{M})$ & 0 & $2.4 \mathrm{~b}$ & 4.5 & 8.9 \\
\hline 0 & $1.0^{\mathrm{y}} \mathrm{c}^{\mathrm{x}}$ & $4.6 \mathrm{a}(1: 11)^{\mathrm{w}}$ & $2.7 \mathrm{~b}$ & $2.8 \mathrm{~b}$ \\
4.4 & $3.7 \mathrm{ab}$ & $4.0 \mathrm{a}(1: 1)$ & $4.4 \mathrm{a}(2: 1)$ \\
8.9 & $3.3 \mathrm{~b}$ & $4.8 \mathrm{a}(1: 22)$ & $4.1 \mathrm{a}(1: 2)$ & $3.8 \mathrm{a}(1: 1)$ \\
17.8 & $4.2 \mathrm{a}$ & $4.7 \mathrm{a}(1: 44)$ & $3.9 \mathrm{a}(1: 4)$ & $4.1 \mathrm{a}(1: 2)$ \\
\hline
\end{tabular}

${ }^{2}$ Ratings are based on a scale where $0=$ dead and $5=$ many shoots or shoot buds.

'Nine to 12 culture tubes per treatment.

xMean separation within columns by single-degree-of-freedom orthogonal contrasts, $P=0.05$. Analysis on data after arcsin transformation; nontransformed data are presented.

wAuxin : cytokinin ratio. 


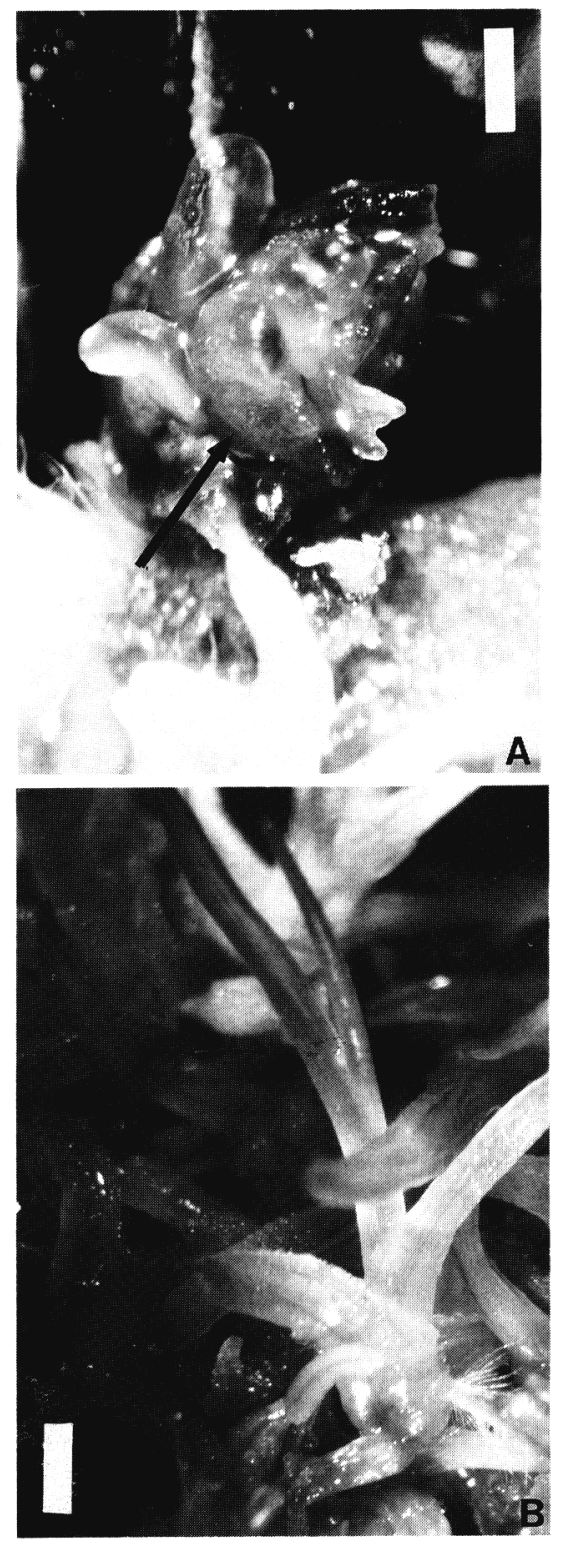

Fig. 1. Morphogenesis in pampas grass initiated on MS basal medium amended with $4.5 \mu \mathrm{M}$ 2,4-D and 4.4 $\mu \mathrm{M} \mathrm{BA}$, and subcultured twice onto medium supplemented with $2,4-\mathrm{D}$ and $\mathrm{BA}$ and then twice onto basal medium without growth regulators. (A) Shoot primordium indicated by the arrow (bar $=0.3 \mathrm{~mm}$ ). (B) Multiple shoots (bar $=0.7 \mathrm{~mm}$ ).

1 month, cultures from the eight initiation media that supported the fastest growth and morphogenesis (rated 4 or 5) were subcultured to each of the following three media: MS basal medium without growth regulators or supplemented with $0.4 \mu \mathrm{M} 2,4-\mathrm{D}$ and either 0.4 or $4.4 \mu \mathrm{M}$ BA. After two passages on one of these media, the cultures were transferred to basal medium without growth regulators.

Rooting studies. Three months after culture initiation, shoots larger than $20 \mathrm{~mm}$ were transferred to one of the following seven rooting media: MS basal medium without growth regulators or supplemented with 4.9, 9.8 , or $19.7 \mu \mathrm{M}$ IBA, or MS basal medium supplemented with $5.4,10.7$, or $21.5 \mu \mathrm{M}$ NAA. At least 25 shoots were cultured on

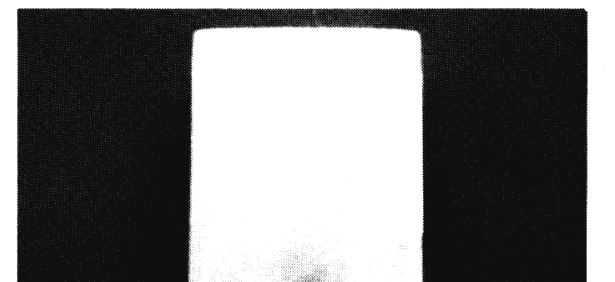

ering in 1989. Inflorescence length gave consistent results over both years. Stage of inflorescence development has been shown to be critical in other grass species, including Paspalum notatum Flügge (Bovo and Mroginski, 1986) and finger millet (Eleusine coracana Gaertn.) (George and Eapen, 1990).

Origin of the. explant from the distal, middle, or proximal part of the inflorescence had no significant effect on explant establishment or growth after 1 month of culture. Similar results were obtained with rye (Secale cereale L.) (Linacero and Vazquez, 1990). Culture of floret, rachilla, and rachis tissues of pampas grass revealed that shoots formed only from floret tissue. Rachilla and rachis tissues died without growing. Grass species apparent\&differ in this regard. For example, big bluestem (Andropogon gerardii Vitm.) initiated callus from the rachis (Chen et al., 1977), whereas wheat (Triticum aestivum L.) formed callus from the rachis and the florets (Ozias-Akins and Vasil, 1982). Like pampas grass, pearl millet (Pennisetum americanum L.) initiated callus from floral primordia (Botti and Vasil, 1984).

Growth regulator effects. Growth ratings taken 1 month after culture initiation revealed significant effects of medium $(P=$ 0.0001 ) for BA and 2,4-D and for the BA $\times 2,4$-D interaction $(P=0.01)$. Because the interaction was significant, BA levels were compared within each level of 2,4-D. Tissues cultured on media without BA had significantly lower growth ratings than those cultured on media with both BA and 2,4-D (Table 1). Shoots had differentiated from explants cultured on basal medium amended with $0.4 \mu \mathrm{M} 2,4-\mathrm{D}$ plus $4.4,8.9$, or 17.8 $\mu \mathrm{M}$ BA and on the medium containing 17.8 $\mu \mathrm{M}$ BA (no 2,4-D). These media had a low auxin : cytokinin ratio. The shoots formed directly from the inflorescence tissue. Direct development of shoots from inflorescence tissue has also been reported in Lolium, Festuca, Phleum, Dactylis (Dale and Dalton, 1983), and finger millet (George and Eapen, 1990). In contrast, tissues cultured on medium containing 4.5 or $9.0 \mu \mathrm{M} 2,4-\mathrm{D}$ and any level of BA had a small amount of hard, green callus and leaves, but no shoots. All cultures lacking a cytokinin showed little growth.

Transfer from initiation media containing 2,4-D and BA to medium without growth regulators caused death of much of the tissue; the tissue that survived formed few shoot buds. However, shoot development and proliferation of shoot buds were observed in all cultures transferred from initiation medium to medium containing $0.4 \mu \mathrm{M} 2,4-\mathrm{D}$ plus 0.4 or $4.4 \mu \mathrm{M}$ BA (Fig. 1A). The most rapid growth occurred in cultures that had been initiated on $4.5 \mu \mathrm{M} 2,4-\mathrm{D}$ plus $8.9 \mu \mathrm{M} \mathrm{BA}$ or $9.0 \mu \mathrm{M} 2,4-\mathrm{D}$ plus $17.8 \mu \mathrm{m}$ BA. Following a third passage on medium containing both 2,4-D and BA, shoot buds and shoots continued to develop, although the shoots had thick, vitrified leaves. Transfer of these tissues to basal medium without growth regulators yielded nonvitrified shoots (Fig. 1B). Six months after culture initiation, the rate 
of multiplication was about three shoots (larger than $20 \mathrm{~mm}$ ) per culture tube per month. However, nearly $50 \%$ of the cultures died, apparently having lost morphogenetic capacity.

Rooting studies. Rooting medium had no significant effect on percent root formation after 1 month. Percent rooted shoots ranged from $12 \%$ to $40 \%$ for the various rooting media; on medium without growth regulators, $35 \%$ of the shoots formed roots. After another month on medium without growth regulators, $77 \%$ of the shoots had roots (Fig. 2 ). Rooting of shoots was related to shoot size, such that larger shoots were more likely to form roots (data not shown).

Acclimatization. More than $99 \%$ of the plants that were transferred to the greenhouse survived. These plants had originated from the various growth regulator treatments described above. No difference in plant survival or growth was observed on rooted vs. unrooted shoots placed in soil. More than 500 plants were hardened to greenhouse conditions, and of these, 150 were transferred to the field. Plants acclimated readily and flowered during their second summer. Only two plants showed an obvious morphological change, i.e., variegated leaf pattern.

Rate of multiplication of pampas grass in vitro greatly exceeded that obtained through the traditional method of division. At least 100 explants were obtained from each inflorescence, and each plant had many inflorescences. We estimate that several thousand plants can be obtained in 1 year from a single inflorescence. This technique would be very useful for rapid propagation of desirable pampas grass cultivars.

\section{Literature Cited}

Bhaskaran, S. and R.H. Smith. 1990. Regeneration in cereal tissue culture: A review. Crop Sci. 30:1328-1337.

Botti, C. and I.K. Vasil. 1984. Ontogeny of somatic embryos of Pennisetum americanum. II. In cultured Immature inflorescences. Can. J. Bot. 62:1629-1635.

Bovo, O.A. and L.A. Mroginski. 1986. Tissue culture in Paspalum (Gramineae): Plant regeneration from cultured inflorescences. J. Plant Physiol. 124:481-492.

Chen, C.H., N.E. Stenberg, and J.G. Ross. 1977. Clonal propagation of big bluestem by tisssue culture. Crop Sci. 17:847-850.

Dale, P.J. and S.J. Dalton. 1983. Immature inflorescence culture in Lolium, Festuca, Phleum and Dactylis. Z. Pflanzenphysiol. 111:39-45.

George, L. and S. Eapen. 1990. High frequency plant-regeneration through direct shoot development and somatic embryogenesis from immature inflorescence cultures of finger millet (Eleusine coracana Gaertn). Euphytica 48:269274.

Linacero, R. and A.M. Vazquez. 1990. Somatic embryogenesis from immature inflorescences of rye. Plant Sci. 72:253-258.

Meyer, M.H. 1975. Ornamental grasses. Charles Scribner's Sons, New York.

Murashige, T. and F. Skoog. 1962. A revised medium for rapid growth and bioassay with tobacco tissue cultures. Physiol. Plant 15:473497.

Ozias-Akins, P. and I.K. Vasil. 1982. Plant regeneration from cultured immature embryos and inflorescences of Triticum aestivum L. (wheat): Evidence for somatic embryogenesis. Protoplasma 110:95-105.

Robacker, C.D. and W.L. Corley. 1988. Regeneration of pampas grass (Cortaderia selloana) from immature inflorescences. HortScience 23(3):759. (Abstr.)

Robacker, C.D. and C.R. Johnson. 1989. Hardening and growth of dwarf pampas (Cortaderia selloana) in response to fertilizer application following in vitro culture. ASHS 1989 Annu. Mtg., Tulsa, Okla., Prog. \& Abstr. p. 81.

SAS Institute, Inc. 1985. SAS user's guide: Statistics, version 5 edition. SAS Institute, Inc., Cary, N.C.

Vasil, I.K. 1987. Developing cell and tissue culture systems for the improvement of cereal and grass crops. J. Plant Physiol. 128:193-218. 